\title{
EFFECT OF DIFFERENT SUBSTRATES AND AUXINS ON ROOTING OF Leucadendron sp. (PROTEACEAE)
}

\section{EFECTO DE DIFERENTES SUSTRATOS Y AUXINAS EN EL ENRAIZAMIENTO DE Leucadendron sp. (PROTEACEAE)}

\author{
Fernando Javier Peña-Baracaldo ${ }^{1}$, Hans Nicolas Chaparro-Zambrano ${ }^{2}$, Andrés Sierra ${ }^{3}$, Julián Rodríguez ${ }^{4}$, \\ Marco Cabezas-Gutiérrez ${ }^{5}$
}

${ }^{1}$ Ing. Agrónomo, M.Sc., Docente-investigador, Programa Ingeniería Agronómica. Universidad de Ciencias Aplicadas y Ambientales U.D.C.A, Calle 222 No. 55-37, Bogotá, D.C., e-mail: fepena@udca.edu.co; ${ }^{2}$ Ing. Agrónomo, M.Sc., Docente-investigador, Programa Ingeniería Agronómica. Universidad de Ciencias Aplicadas y Ambientales U.D.C.A, Calle 222 No. $55-$ 37, Bogotá, D.C., e-mail: hchaparro@udca.edu.co, @iDhttps://orcid.org/0000-0002-4355-8050; ${ }^{3}$ Ing. Agrónomo, egresado Universidad de Ciencias Aplicadas y Ambientales U.D.C.A, Calle 222 No. 55-37, e-mail: andres_8730@hotmail.com; ${ }^{4}$ Ing. Agrónomo, egresado Universidad de Ciencias Aplicadas y Ambientales U.D.C.A, Calle 222 No. 55-37, e-mail: julianrodriguezleon@gmail.com; ${ }^{5}$ Ing. Agrónomo, M.Sc. Universidad Nacional de Colombia, e-mail: mcabezasg@unal.edu.co, (Dhttps:// orcid.org/0000-0001-9072-7681

Rev. U.D.C.A Act. \& Div. Cient. 21(2): 385-393, Julio-Diciembre, 2018 https://doi.org/10.31910/rudca.v21.n2.2018.968

Open access article published by Revista U.D.C.A Actualidad \& Divulgación Científica under a Creative Commons CC BY-NC 4.0 International License

\begin{abstract}
Colombian flower growers are faced with economic and social problems, so they are looking for alternatives, which include Proteas, ornamentals that require research that ensures an appropriate, local technical management. One of the Proteas most likely to be involved in this search is the genus Leucadendron. Therefore, this study aimed to establish the best basis for rooting its cuttings. The experimental design was a split plot design with a factorial arrangement. Four substrates were evaluated in combination with two auxins, naphthaleneacetic acid (NAA) and indolebutiric acid (IBA), three doses each, plus a commercial control. Each treatment was repeated three times and the experimental unit consisted of 30 stakes at the first locality and 25 at the second one. The most relevant results showed that vermiculite was the best substrate for rooting cuttings of Leucadendron at both localities. Also, it was identified that IBA is the growth regulator which improved the rooting percentage, the root volume, the stem decreased the percentage of losses.
\end{abstract}

Keywords: asexual propagation, auxin, rice husks, vermiculite, slag, peat.

\section{RESUMEN}

Los cultivadores colombianos de flores tradicionales están confrontados con problemas, tanto económicos como sociales, por lo que están buscando alternativas, que incluyen a las Proteas, ornamentales que requieren investigación, que asegura un manejo técnico. Una de las Proteas con más posibilidad de estar involucrado en este desarrollo es el género Leucadendron. El diseño experimental empleado fue un diseño de parcelas, divididas con arreglo factorial. Así, que el objetivo de este estudio fue establecer la base para el enraizamiento de las estacas. En combinación con dos auxinas, ácido 1-naftalenacético (ANA) y ácido indolbutírico (AIB), tres dosis de cada una y el control comercial, se evaluaron cuatro sustratos. Cada tratamiento, se repitió tres veces y cada unidad experimental consistió en 30 estacas, para la primera localidad y de 25, para la segunda. Los resultados más relevantes mostraron que el mejor sustrato para el enraizamiento de estacas de Leucadendron fue la vermiculita, en ambas localidades. También, se identificó que AIB es el regulador de crecimiento que mejoró el porcentaje de enraizamiento, el volumen de raíces, la longitud del tallo disminuyó el porcentaje de pérdidas.

Palabras clave: propagación asexual, auxinas, cascarilla de arroz, vermiculite, escoria, turba. 


\section{INTRODUCTION}

Colombian's floriculture sector is undergoing an economic and social crisis, resulting from macroeconomic changes and tariff policies, which lead to the closure of several prestigious companies, and the looking for alternatives to ensure their sustainability. Planting and marketing of new species of cut flowers and bouquets companions, has shown guarantee for exporters, because the market has been growing in demand for these products. As an added value the fact that plants can be grown at free exposure in small areas, with easy technological management, important aspects for the economy of small scale, has been identified (Barker et al. 2004).

Proteas are plants of tropical origin, grown open in countries like South Africa, Madagascar and Tanzania (Barker et al. 2004). In the Savannah of Bogotá, efforts have been made to implement the crop, but there are problems in propagation and technical management; plant material is imported through Ecuadorian and Israel companies, which does not necessarily guarantee the expected quality.

In Spain, Leucadendron is propagated by cuttings, technology also used in other countries (Janick, 2007). The quality of rooted cuttings depends on the source material, the variety and the agronomic practices under which they are produced; among those the substrates and auxin used, their dose and application and environmental conditions stand out (Hartmann et al. 2002).

For rooting of many plant species the auxins used are mainly indole butyric acid (IBA) and naphthaleneacetic acid (NAA), because they are more effective in inducing root formation (Weaver, 1996). Castrillón et al. (2008) showed that IBA was more efficient for rooting 'Agraz' (Vaccinium meridionale) cuttings, compared with indole acetic acid (IAA).

This research pretended to obtain the best efficiency of rooting cuttings of the protea Leucadendron, at lowest loss, evaluating four types of substrates and three doses of IBA and NAA at Bogotá's savannah.

\section{MATERIALS AND METHODS}

The study was conducted under greenhouse conditions in the Savannah of Bogotá, in the research unit of 'El Remanso' at the Universidad de Ciencias Aplicadas y Ambientales U.D.C.A.

A split plot design with factorial arrangement was used. three substrates (peat and vermiculite, slag) and two hormones (IBA and NAA) at three different concentrations (500, 1000 and 2000ppm), were evaluated by treatment.
Vegetal material was stakes of $15 \mathrm{~cm}$ in length, being cut cross the basal stake upper cut and skew cut were used; basal leaves were removed from each stake. Stakes were obtained from productive plants, vegetative stems were taken and cut. Subsequently of the cut and defoliation, treatment with Vitavax 300 WP was performed at a dose of $2 \mathrm{~g} / \mathrm{L}$ of water for 3 minutes, then immersed for 30 seconds in the respective treatment. Finally, in the locality 1 for each treatment were immersed 30 stakes and settled in the respective substrate vertically; in the locality 2 the same procedure was performed, the only difference was the use of 25 stakes.

The experiment was performed in a cycle of 20 weeks. During this period, the stakes were watered with a misting system with irrigation frequencies and intervals, depending on ambient humidity and temperature conditions.

Variables measured: At the end of 20 weeks, the following variables were measured in a sample of 10 cuttings:

For fresh and dry mass of the plant the samples were weighed entirely fresh and subsequently dried in the oven until constant dry weight. To determine root volume, the samples were washed under pressure to remove the substrate adhered to the roots. Subsequently they were introduced into a test tube marked in mililiters (ml), filled with water to quantify the volume occupied by the root. For length of the aboveground parts was determined by the measure of regrowth of each stake from the base of the plant to the apical meristem.

Statistical analysis: The assumptions of normality and homogeneity of variances using the Levene test were evaluated using the SAS statistical package. The data which did not show normality were transformed with the function arcosen $\sqrt{ }(\mathrm{x} / 100)$, then an ANAVA was carried out and the differences between treatments was evaluated by Tukey's comparing method $(P<0,05)$ test. In all cases the statistical package SAS (Statistical Analysis System), version 9.1 was used.

\section{RESULTS AND DISCUSSION}

Variables responses: In the Leucadendrom stakes, there was a highly significant effect $(P \leq 0,001)$ of the substrate and the interaction between the substrate and the application of plant growth regulators on rooting percentage. However, there was no difference in the effect of the application of plant growth regulators on the rooting percentage (Table 1). Percentage loss of stakes showed a highly significant effect $(P \leq 0,001)$ of substrate and the interaction between the substrate and the application of plant growth regulators on the percentage of loss. No difference in the effect of the application of plant growth regulators on loss of stakes was detected (Table 1 ). In root volume a highly significant effect $(P \leq 0,001)$ was obtained for substrate and the interaction between the 
Table 1. Significance of the $\mathrm{F}$ test for the effect of substrate, application of plant growth regulators on rooting \%, Loss \%, Root volume \%, length of stem cuttings (cm), Dry weight ( $\mathrm{gr}$ ) of Leucadendron sp. $* * *=\mathrm{P}<0.001, * *=\mathrm{P}<0.01, *=\mathrm{P}<0.05$, $\mathrm{NS}=$ no Significance.

\begin{tabular}{|l|c|c|c|c|c|c|c|c|c|c|}
\hline \multirow{2}{*}{ Variable } & \multicolumn{2}{|c|}{ Rooting (\%) } & \multicolumn{2}{c|}{ Loss (\%) } & \multicolumn{2}{c|}{ Root volume (\%) } & \multicolumn{2}{c|}{$\begin{array}{c}\text { Lenght of stem } \\
\text { (cm) }\end{array}$} & \multicolumn{2}{c|}{ Dry weight (gr) } \\
\hline Statistic & CM & Sig & CM & Sig & CM & Sig & CM & Sig & CM & Sig \\
\hline Substrate (Subst) & 3,482 & $* * *$ & 0,066 & $* * *$ & 11,963 & $* * *$ & 57,5 & $* *$ & 6,614 & $* * *$ \\
\hline Phytoregulator (Phytreg) & 0,067 & NS & 0,006 & NS & 0,449 & NS & 16,136 & $*$ & 0,227 & NS \\
\hline Phytreg $x$ Subst & 0.382 & $* * *$ & 0.010 & $* *$ & 1.462 & $* * *$ & 13,486 & $*$ & 1.263 & $* *$ \\
\hline
\end{tabular}

substrate and the application of plant growth regulators on the root volume. However, there was no difference in the effect of the application of plant growth regulators on the variable (Table 1). On the length of stem cuttings Leucadendrom (Table 1), the stakes showed significant effects of the application of plant growth regulators, the substrate and their interaction on stem length $(P \leq 0.05)$ (Table 1).

The results in this study are compelling and clearly define the substrate; auxin type and concentration to favor the generation of adventitious roots in cuttings Leucadendron. Although peat is favorable to produce biomass fresh medium, having a high initial nutrient content, high moisture retention and adequate aeration and porosity (Álvarez Herrera et al. 2007), the vermiculite substrate regardless of the treatment of cuttings with IBA and NAA regulators, generate the highest values for most variables assessed in the propagation system producer, consisting in the use of slag substrate and treatment of cuttings with IBA and NAA 500, 1000 and 2000ppm. Furthermore, the use of a mixture with soil substrate - slag ratio $8: 2$ and treatment of cuttings with a mixture of IBA and NAA equally to $1500 \mathrm{ppm}$, with the roots in peat and vermiculite plus three doses of IBA and NAA. Similar results were found in other species of Proteaceae. Gouws et al. (1990) reported that in general the cuts should be treated with IBA at concentrations between 1000-4000ppm to improve rooting. The substrate which showed better results under our conditions was vermiculite, which may be due to its physic-chemical characteristics. Similar results were found by Cárdenas-Navarro \& López-Pérez (2011), in roses and Nguyen et al. (1999) and Mills et al. (2009), spreading jojoba and coffee, where success in root development was partly due to the good aeration capacity of the vermiculite substrate. Substrates differ in their water holding capacity and thus their relationship air: water. This is determinative of the air gap of the substrates and which provides oxygen for respiration (Hartmann et al. 2002). Bunt (1983) noted that vermiculite does not have anion exchange capacity, however it can adsorb phosphate forms available to the plant, which is a beneficial factor because phosphates are constituents of nucleic acids and phospholipids, as well as being essential for cell division and development of meristematic tissues (Wild \& Jones, 1992).

Several studies of rooting in vermiculite have shown that with this substrate the larger size is reached in all variables: stem diameter, stem height, wet and dry weight of whole plant dry weight of shoot and root weight dry the main root and secondary roots dry weight. In addition, rates have been evaluated to determine the quality of the plant, which showed vermiculite substrates for the best behavior (Di Benedetto et al. 2002; Olivo \& Buduba, 2006).

Rooting percentage (\%): The plants sown in vermiculite substrate showed a high percentage of rooting (RP) compared with slag and peat (Figure 1), however, for this substrate no difference between treatment with AIB or ANA was evident. Although the application of $2000 \mathrm{ppm}$ and $1000 \mathrm{ppm}$ AlB ANA a RP of $90 \%$ was obtained, there were no significant differences in treatment where there was no application of plant growth regulators (83\%). However, other treatments on the same substrate caused a negative effect on this variable, as can be seen for AIB at concentrations of 500, 1000 ppm and ANA at a concentration of $500 \mathrm{ppm}$, which decreased their $\mathrm{RP}$ of 70,73 and $58 \%$ respectively compared to the absolute control. It is possible to show a positive interaction between the effect of the application of AIB and ANA and the effect of planting the cuttings in peat substrate. Treatment with the two plant growth regulators at all concentrations (except ANA 500 ppm) increased the stakes RP Leucadendrom sp. with no statistical difference between them. In the slag substrate lower values for the variable RP obtained and no positive effect of treatment of cuttings with ANA or AIB AIB 1000ppm except that slightly increases the value of this variable in this substrate evidence. These results indicate that the variable $\mathrm{RP}$ response in terms of increasing their value is influenced in a major way by the type of substrate by treatment with AIB or ANA. Also it may be noted that the interaction is positive only in terms of the increase of the variable, when it is used as rooting substrate peat and most plant growth regulators concen- 
trations for both. Schiappacasse et al. (2003) reported that with the cultivar Leucadendron cv. Safari Sunset best rooting percentage $(74 \%)$ was obtained by treating subterminal cuttings, with 4000ppm of indole butyric acid in liquid form. In stakes Protea 'Susara' (P. magnifica x P. susannae) were evaluated three doses of AIBA (0, 2000 and 4000ppm) in four types of cuttings (terminals, baseline, the last flow growth and cuts terminal and subterminal). Other authors reported that the best results were observed using terminals and basal cuttings treated with IBA 4000 ppm (Rodríguez-Pérez et al. 2009). Rodríguez-Pérez et al. (1997) informed that terminals and basal cuttings of Leucadendron discolor, treated with 4000 ppm of IBA at 20 weeks showed a high percentage of rooting (58-85\%). In Leucospermum cordifolium, at week 12 , terminals stakes treated with 4000 ppm of IBA generated a rooting percentage of $86.7 \%$ (Rodríguez-Pérez et al. 2001). In Leucospermum "Succession II" (L. cordifolioum x L. lineare) a rooting percentage of $95 \%$ was obtained, 8 weeks after treatment of terminal cuttings with $4000 \mathrm{ppm}$ of IBA. In basal cuttings rooting percentage was $45 \%$ when they were treated with 2000 ppm of IBA (Rodríguez-Pérez et al. 2003). In other species, Vidala et al. (2009) evaluated the effect of concentrations of IBA $(0,250,500,1000$ and 1500ppm) on stakes of Eucryphia glutinosa, finding that the best results occurred at the concentration of 500ppm IBA, with 56,5\% rooting. Oliva et al. (2005) working with stakes of Myrciaria

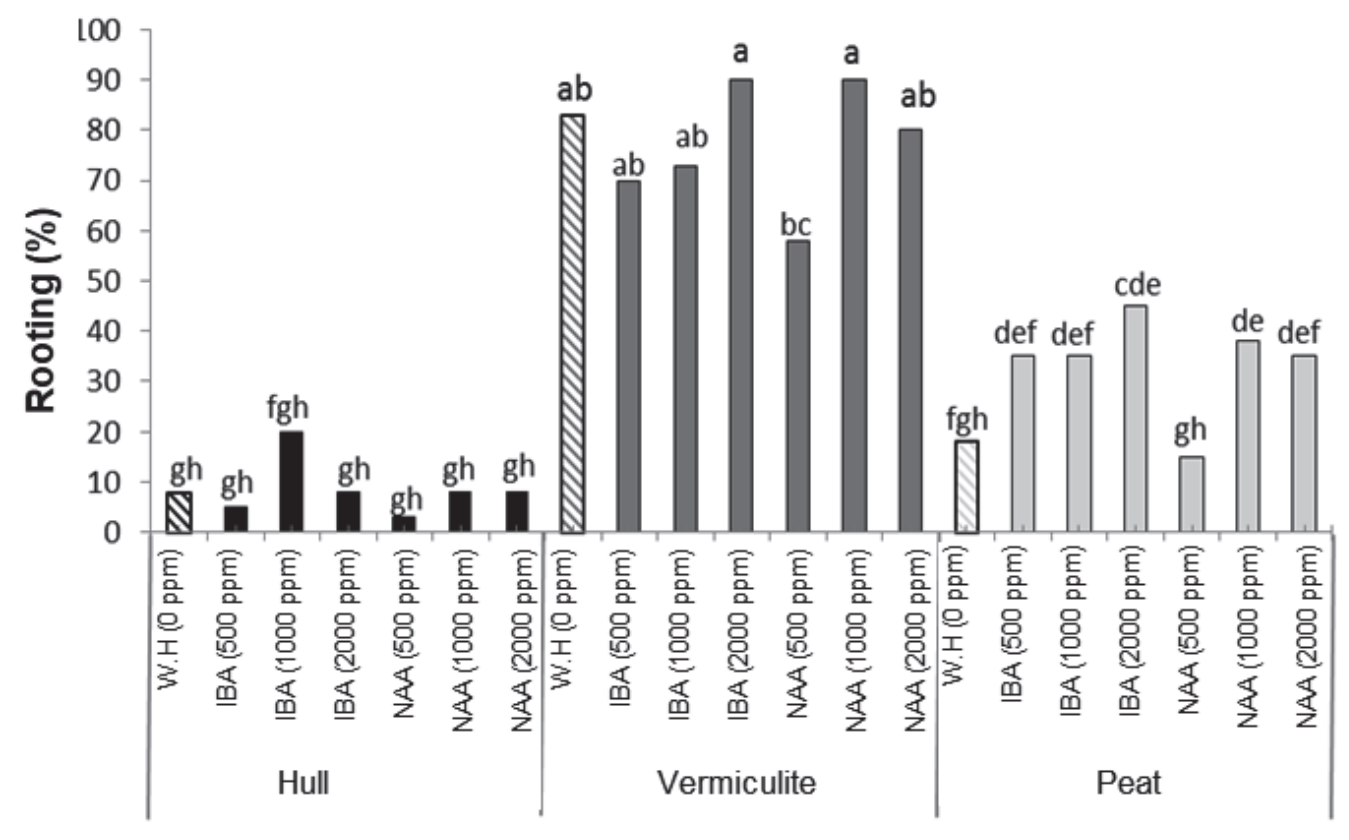

Figure 1. Effect of substrate type and treatment with three doses of IBA and NAA on rooting percentage of stakes Leucadendron to 124 days after established. Columns with different letters indicate significant differences (Tukey $\mathrm{P}<0,05)$. W.H $=$ no hormone.

dubia found that 400ppm IBa + NAA was the best treatment generating 40,73 to $55,57 \%$ rooting and varying immersion times in 24 and 48 hours. Desfontainia stakes in peat substrate spinosa - perlite (1: 1) reached rooting percentages of $67-82 \%$ using IBA concentrations of $1000-4000$ ppm. By contrast, Laureliopsis philippiana on the same substrate had lower values of rooting (33\%) for the cuttings treated with 4000ppm of IBA (Delgado et al. 2008).
Percentage Loss: The percentage of material lost during the rooting process was substantially lower (Figure 2) of stakes planted in the vermiculite substrate, compared to other substrates. Again, no effect of plant growth regulators applying this substrate was observed, which is in contrast with that perceived in the peat substrate. In this substrate material losses were increased with the treatment of cuttings with AIB at all concentrations, being 1000 ppm AIB which had the highest percentage loss (22\%). In the slag material substrate significant losses were also presented, but material losses 


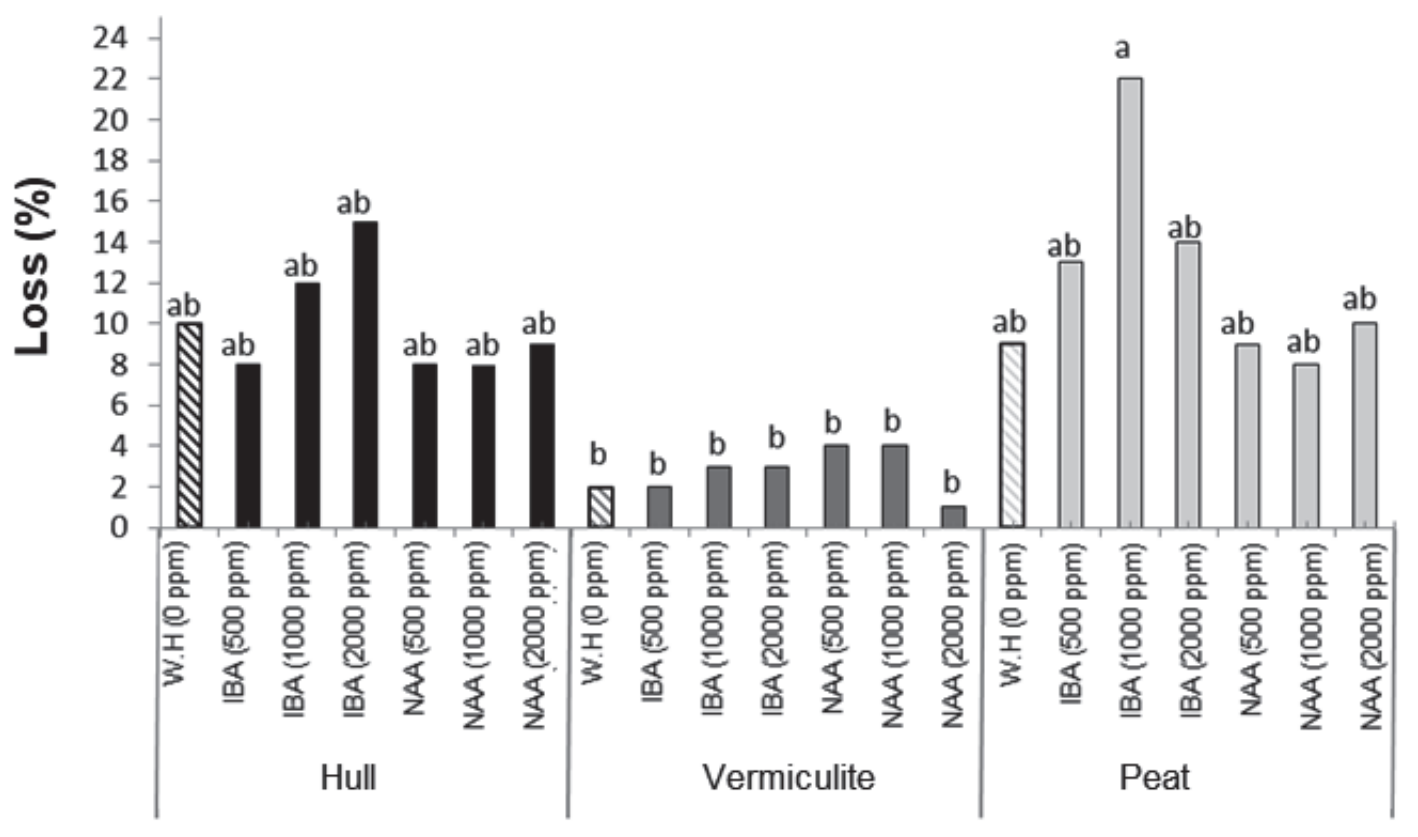

Figure 2. Effect of substrate type and treatment with three doses of IBA and NAA on loss percentage stakes Leucadendron 124 days after established. Columns with different letters indicate significant differences (Tukey $\mathrm{P}<0,05$ ). W.H $=$ no hormone.

were diminished when the stakes were treated with ANA at all concentrations (Figure 2).

In this research the high percentages of loss, mainly in scale and slag could have been caused by the low water retention capacity which means a water shortage causing the death of stakes. The stakes are prone to water stress until the roots are formed and allow the uptake and absorption of water for the maintenance of cell turgor and development of new roots (Puri \& Thompson, 2003). Most moisture holding capacity of peat and vermiculite ( 48 and $45 \%$, respectively), can generate a lower percentage of loss. However, in the peat, this was not reflected in an increase in the development of adventitious roots in terms of percentage.

Root volume: In the vermiculite substrate significant differences between treatments and control plant growth regulators observed (Figure 3). Both AIB at 1000 and 2000 ppm as ANA in 1000 and 2000ppm contributed to the increase of this variable reached values of $1.34,2.08,1.33$ and $1.41 \mathrm{ml}$, respectively, compared to control $(1.04 \mathrm{ml})$ indicating a positive interaction between the substrate and plant growth regulators treatment. In the peat substrate, the stakes treated with AIB at all concentrations and ANA in 1000 and 2000ppm tended to increase their volume of roots compared with the control, without statistical differences in their values are evidenced. You can highlight treatment with 2000ppm
AIB which reached a value of $0,445 \mathrm{ml}$, which is higher than the other treatments and the control $(0,065 \mathrm{ml})$. The stakes planted in slag had the lowest values for the variable, between 0.02 and 0.07, even with the application of AIB and ANA, being the highest value generated 1000ppm of AIB (Figure 3). The study observed a significant effect of exogenous auxin application on rhizogenesis of Leucadendron sp. This is because the plant hormones (ethylene, gibberellins, cytokinins, auxins and growth inhibitors, such as abscisic acid), auxins are those that have the greatest effect on the formation of roots (Hartmann et al. 2002). The positive effect of the application of auxins on the increase in volume of roots and dry weight, is that by increasing the auxin content cell elongation increases, since auxins acidifies the cell wall, generating loss stiffness action expansions; proteins causing distention of the cell walls by weakening the hydrogen bonds between polysaccharides and cell wall components; then the cell expands the water inlet (Taiz \& Zeiger, 2006), which increased water content of the plant and also more fresh dough. The auxin indole-3-acetic acid (IAA) is a natural hormone that promotes the formation of adventitious roots. Synthetic forms, such as indol-butyric acid (IBA) and naphthalene (NAA), are more effective than the AIA to stimulate root formation in cuttings, because they are not toxic to plants in a wide range of concentrations and stimulate rooting in a large number of species, and a greater photo stability (Hartmann et al. 2002). It is also possible that this 


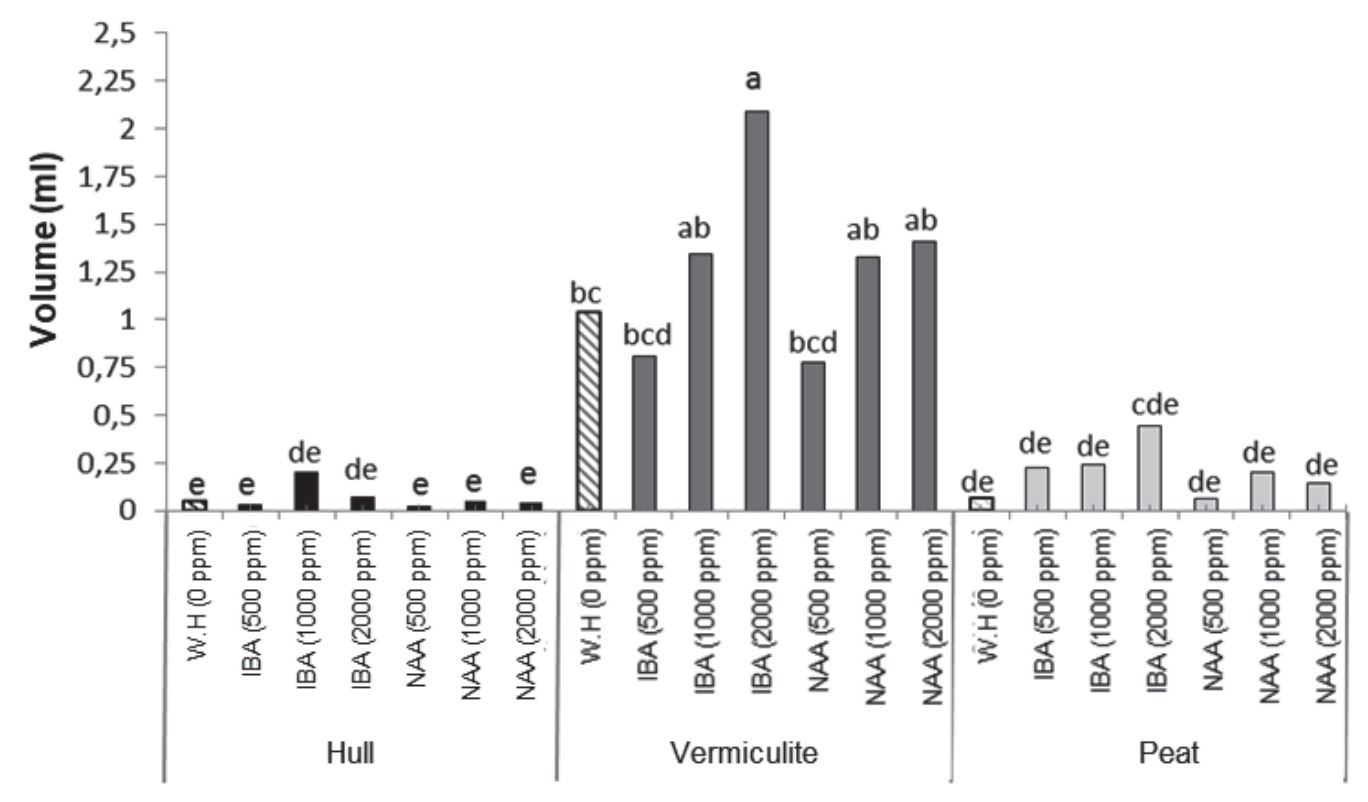

Figure 3. Effect of substrate type and treatment with three doses of IBA and NAA on volume (ml) root cuttings Leucadendron sp. 124 days after established. Columns with different letters indicate significant differences (Tukey $\mathrm{P}<0,05$ ). W.H $=$ no hormone.

auxin is more stable chemically than NAA in contact with the substrate propagation. It is also a substance of localized action and less sensitive to biological degradation compared to other synthetic auxin (Fachinello et al. 1995).

This higher volume of rooted cuttings without IBA application is related to the endogenous hormonal balance favorable cytokinin-auxin for callus formation, since a higher concentration of cytokinin, ie, high cytokinin-auxin ratio favors the formation undifferentiated cells that give rise to callus; therefore if the relationship through the exogenously auxin application is decreased, the division and differentiation of cells is favored, giving rise to the formation of adventitious roots, to the detriment of callus formation (Salisbury \& Ross, 1992).

Stem length: The influence of the substrate and the application of IBA and NAA on stem length (SL) Leucadendron stakes can be seen in figure 4 . The stakes control treatment (no treatment with plant growth regulators) sown in vermiculite substrate had greater stem length $(10,72 \mathrm{~cm})$ compared with other treatments. In this case the increase in the SL is favored only by the type of substrate; the application of IBA or NAA results in a decrease in the value of the variable, which is clearly seen by comparing the results of the check (cuttings without treatment with plant growth regulators) of each substrate with corresponding treatments.
In the slag substrate variations between treatments are observed, however, in this substrate there is no statistical difference between the control $(7,6 \mathrm{~cm})$ and concentrations of AIB and ANA, although these values tend to be lower than the control, which is in the low value of SL generated by the application of AIB to 2000ppm $(3,8 \mathrm{~cm})$. The witness in the peat substrate and ANA to 2000ppm had the highest value of SL $(6,2 \mathrm{~cm})$, followed by AIB 500 ppm $(5,62 \mathrm{~cm})$, plant growth regulators other treatments had lower values than the control (Figure 4). Puri \& Thompson (2003) describes that is the moist in the substrate that increase the develop of the stem cuttings. Otherwise auxins diminish the stem length because they modify the auxins gibberellins ratio, this low in rate ofgibberellins affects the increase of stem length on plants (Taiz \& Zeiger, 2006). Vermiculite is light in weight and has a structure in plates, which generates high surface / volume ratio and therefore a high capacity for moisture retention. The plates contain numerous sites to retain cations, both externally and internally, resulting in a high cation exchange capacity; such property is unique to the inorganic components of growth media, which are typically inert (Cárdenas-Navarro \& López-Pérez, 2011).

Dry weight: Stakes (Figure 5) without any treatment of plant growth regulators sown in the vermiculite substrate had a value DW $(5,27 \mathrm{~g})$ significantly greater than the value obtained in most treatments. The same trend can be seen in the peat 


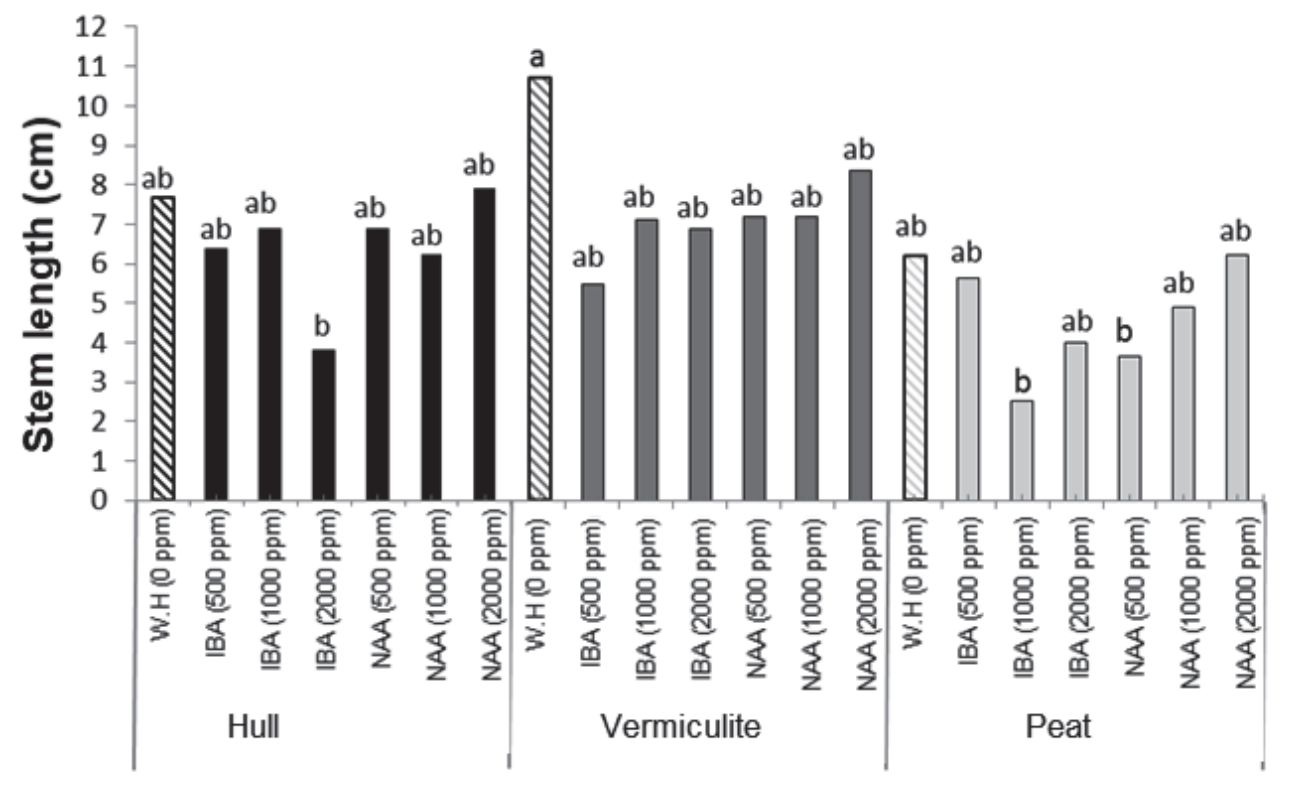

Figure 4. Effect of substrate type and treatment with three doses of IBA and NAA on length of stem (cm) cuttings Leucadendrom sp. to 124 days after established. Columns with different letters indicate significant differences (Tukey P $<0,05$ ). W.H $=$ no hormone.

and slag substrates where the checks DW show a higher $(3,75$ and $4,20 \mathrm{~g}$, respectively), but not significantly, than those found when cuttings were treated with IBA and NAA.
In this case the increase in DW is favored only by the type of substrate and not by the application of phytoregulators that would further decrease or block the positive effect of the

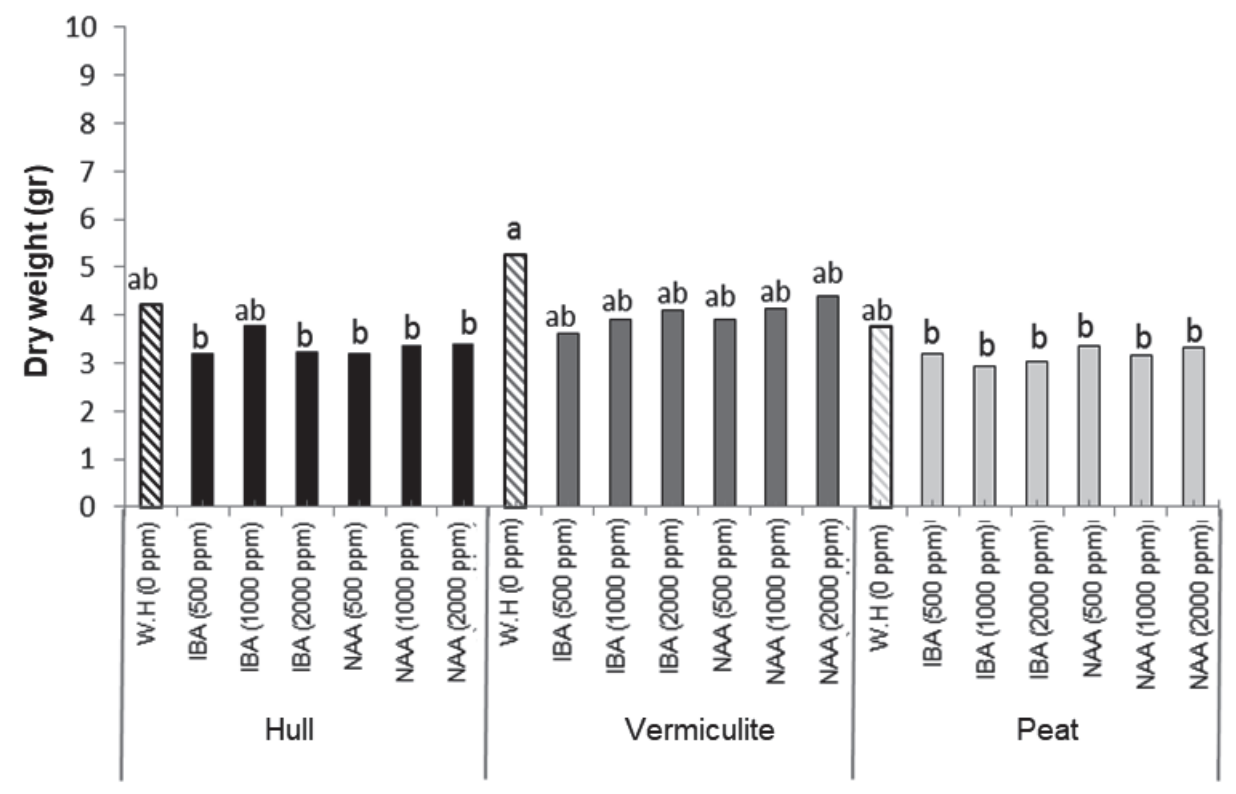

Figure 5. Effect of substrate type and treatment with three doses of IBA and NAA on dry weight ( $\mathrm{gr}$ ) of stakes Leucadendron sp. 124 days after established. Columns with different letters indicate significant differences (Tukey P $<0,05$ ). W.H $=$ no hormone. 
substrate (Figure 5). Growth responses of stakes is defined by environmental conditions, the supply of water, nutrients, energy and air propagation medium can bring you, as well as the genetic load (Taiz \& Zeiger, 2006). Also, the process of rooting of stakes is controlled by a combination of physiological processes, both the leaves and stem, environmental factors and propagation conditions. As an optimal combination of these factors favor the successful propagation.

Conflicts of interest: The manuscript was prepared and revised by all authors, who declare the absence of any conflict which can put the validity of the presented results in risk.

\section{REFERENCES}

1. ÁLVAREZ-HERRERA, J.G.; RODRÍGUEZ, S.L.; CHACON, E. 2007. Efecto de diferentes tamaños de esqueje y sustratos en la propagación del romero (Rosmarinus officinalis L.). Agron. Colomb. 25(2):224-230.

2. BARKER, N.; VANDERPOORTEN, P.A.; MORTON, C.M.; ROURKE, J.P. 2004. Phylogeny, biogeography, and the evolution of life history traits in Leucadendron (Proteaceacea). Molecular phylogenetic and Evolution. 33:845-860.

3. BUNT, A. 1983. Physical properties of mixtures of peats and mineral off different particle size and bulck density for potting substrates. Acta Horticulturae. 150:143-153.

4. CÁRDENAS-NAVARRO, R.; LÓPEZ-PÉREZ, L. 2011. Vegetative propagation of rose: effects of substrate, light and leaf persistence. Scientia Agropecuaria. 2:203-211.

5. CASTRILLÓN, J.; CARVAJAL, E.; LIGARRETO, G.; MAGNITSKIY, S. 2008. El efecto de auxinas sobre el enraizamiento de las estacas de. agraz (Vaccinium meridionale Swartz) en diferentes sustratos. Agronomía Colombiana. 26(1):16-22.

6. DELGADO, F.; CUBAB, M.; HECHENLEITNERA, P.; THIERSA, O. 2008. Propagación vegetativa de taique (Desfontainia spinosa) y tepa (Laureliopsis philippiana) con fines ornamentales. Bosque. 29(2):120-126.

7. DI BENEDETTO, A.; KLASMAN, R.; BOSCHI, C. 2002. Evaluación de la formulación de tres substratos en base al uso de turba fueguina para Impatiens walleriana. Agro Sur. 30(2):35-42.
8. FACHINELLO, J.C.; HOFFMANN, A.; NACHTIGAL, J.C.; KERSTEN, E.; FORTES, G.R. 1995. Propagacao de plantas frutiferas de clima temperado. $2 \mathrm{a}$ ed. Ufpel, Pelotas, Brasil.

9. GOUWS, L.; JACOBS, G.; STRYDOM, D.K. 1990. Factors affecting rooting and auxin absorption in stem cuttings of protea. J. Hort. Sci. 65:59-63.

10. HARTMANN, H.T.; KESTER, D.E.; DAVIES, F.T.; GENEVE, R.L. 2002. Plant propagation: principles and practices. 7a ed. Prentice Hall, Saddle River, NJ.

11. JANICK, J. 2007. Proteaceous ornamentals: Banksia, Leucadendron, Leucospermum, and Protea. International Society for Horticultural Science (ISHS). Scripta Horticulturae Number 5. 159p.

12. MILLS, D.; YANQING, Z.; BENZIONI, A. 2009. Effect of substrate, medium composition, irradiance and ventilation on jojoba plantlets at the rooting stage of micropropagation. Scientia Horticulturae. 121:113-118.

13. NGUYEN, Q.T.; KOZAI, T.; NGUYEN, U.V. 1999. Effects of sucrose concentration, supporting material and number of air exchanges of the vessel on the growth of in vitro coffee plantlets. Plant Cell Tissue and Organ Culture. 58:51-57.

14. OLIVA, C.; VARGAS, V.; LINARES, C. 2005. Selection of promising mother plants of Myrciaria dubia (HBK) Mc Vaugh, bush camu-camu, in Ucayali, Peru. Folia Amazónica.14(2):85-89.

15. OLIVO, V.; BUDUBA, C. 2006. Influencia de seis sustratos en el crecimiento de Pinus ponderosa producido en contenedores bajo condiciones de invernáculo. Bosque. 27(3):267-271.

16. PURI, S.; THOMPSON, F.B. 2003. Relationship of water to adventitious rooting in stem cuttings of Populus species. Agroforest, System. 58:1-9.

17. RODRÍGUEZ-PÉREZ, J.A.; VERA-BATISTA, M.C.; DE LEÓN-HERNÁNDEZ, A.M.; ARMAS-ARMAS, P.C. 2001. Influence of cutting position, wounding and IBA on the rooting of Leucospermum cordifolium 'California sunshine' cuttings. Acta Hort. 545:171-177.

18. RODRÍGUEZ-PÉREZ, J.A.; VERA-BATISTA, M.C.; DE LEÓN-HERNÁNDEZ, A.M.; HOYOS RODRÍGUEZ, 
M.C. 1997. Influence of cutting position, wounding and IBA on the rooting of Leucadendron discolor stem cuttings. Acta Hort. (ISHS) 453:29-34.

19. RODRÍGUEZ-PÉREZ, J.A.; VERA-BATISTA, M.C.; DE LEÓN-HERNÁNDEZ, A.M.; RODRÍGUEZ-HERNÁNDEZ, I. 2009. Vegetative Cutting propagation of Protea Hybrid 'Susara' (Proteaceae) Europ. J. Hort. Sci. 74(4):175-179.

20. RODRÍGUEZ-PÉREZ, J.A.; VERA-BATISTA, M.C.; DE LEÓN-HERNÁNDEZ, A.M. 2003. The effect of cutting position, wounding and IBA on the rooting of Leucosperium 'succession ii' stem cuttings. Acta Hort. 602:133-140.

21. SALISBURY, F.B.; ROSS, W. 1992. Plant Physiology. $4^{\text {th }}$ ed.' Belmont, Calif.: Wadsworth Pub. Co., 682p.

22. SCHIAPPACASSE, F.; VICO, V.; YANEZ, P.; HETTICH, W. 2003. Evaluación del cultivo de Leucadendron sp. cv. safari sunset para flor cortada en un valle interior del secano costero de la VII región, Chile. Agric. Téc. [online].63(4):436-442.
23. TAIZ, L.; ZEIGER, E. 2006. Plant physiology. 4a ed. Sinauer Associates Publishers, Sunderland, MA. p.764

24. VIDALA, M.; DELGADO, P.; DELGADO, J. 2009. Efecto del ácido indolbutírico en la capacidad rizogénica de estacas de Eucryphia glutinosa. Bosque. 30(2):102-105.

25. WEAVER, R. 1996. Reguladores del crecimiento de las plantas en la agricultura. Editorial Trillas. Octava impresión. México D.F. 622p.

26. WILD, A.; JONES, L.H.P. 1992. Nutrición mineral de las plantas cultivadas. En: Wild, A. (ed.). Condiciones del suelo y desarrollo de las plantas según Russel. Ediciones Mundi Prensa, Madrid. p.73-119.

Received: February 6, 2018

Accepted: June 18, 2018

How to cite:

Peña-Baracaldo, F.J.; Chaparro-Zambrano, H.N.; Sierra, A.; Rodríguez, J. Cabezas-Gutiérrez, M. 2018. Effect of different substrates and auxins in rooting of Leucadendron sp. (Proteaceae). Rev. U.D.C.A Act. \& Div. Cient. 21(2):385-393, https://doi.org/10.31910/rudca.v21.n2.2018.968 